\title{
ANTIBACTERIAL ACTIVITIES OF Piper sarmentosum (KADUK) METHANOLIC EXTRACT
}

\author{
Maizatul Akma Ibrahim, Syaza Sailah Mohd Nazir \\ Department of Plant Science, Kulliyyah of Science, International Islamic University Malaysia, Jalan Sultan Ahmad Shah, Bandar Indera Mahkota, \\ 25200 Kuantan, Pahang, Malaysia \\ *Corresponding author e-mail: maizatulakma@iium.edu.my
}

This is an open access article distributed under the Creative Commons Attribution License, which permits unrestricted use, distribution, and reproduction in any medium, provided the original work is properly cited.

\section{ARTICLE DETAILS}

\section{Article History:}

Received 20 July 2019

Accepted 24 August 2019

Available online 17 October 2019

\section{ABSTRACT}

Piper sarmentosum or locally known as Kaduk is a tropical herbal plant that is well established for many traditional medicinal purposes. The antibacterial properties of methanolic extract for P. sarmentosum leaves have been investigated in this study. From the disc diffusion test, the methanolic extract of $P$. sarmentosum was found to be active against Gram-positive bacteria namely Staphylococcus saprophyticus (ATCC 15305) and Staphylococcus aureus (ATCC 25923) with zone of inhibition at 17.1 and $11.3 \mathrm{~mm}$, respectively. Meanwhile, the extract showed no or minimal activity against Gram-negative bacteria (Klebsiella pneumoniae ATCC 700603, Pseudomonas aeroginosa ATCC 27853, Enterococcus aerogenes ATCC 13048, Shigella flexneri IMR S $430 / 07$ B, Salmonella typhimurium IMR S 974/05 B) as well as Gram-positive bacteria of Bacillus subtilis (IMR B145/11C). Accordingly, further study by Minimum Inhibitory Concentration (MIC) and Minimum Bactericidal Concentration (MBC) were conducted on $S$. saprophyticus and S. Aureus. The MIC value of methanolic extract for the tested S. saprophyticus and S. aureus were both at $7.5 \mathrm{mg} / \mathrm{mL}$. The MBC showed bacteriostatic for S. saprophyticus and S. aureus at $15 \mathrm{mg} / \mathrm{mL}$. The result of this study indicated that this Piper plant extract can be potential antibacterial agent in the future if the active component can be identified.

\section{KEYWORDS}

Piper sarmentosum, Kaduk, methanolic extract, antibacterial activity.

\section{INTRODUCTION}

People in ancient times utilized the benefits of medicinal plants to improve their health and well-being. Southeast countries especially are well-known for their diversity of flora and this inclined the interest of researchers to discover the true potential of the available local plants. Malaysia is a rich country in term of herbal plants. Many of the medicinal plant possess antimicrobial properties. A number of these plants have been screened to search for antimicrobial components as people nowadays looking for safer and better ways to combat bacterial and fungal infections [1]. Some researchers noted that natural products of natural sources are available in most of the drugs today while has been practically used in traditional systems of medicine [2].

Piper species were claimed to possess pharmacological properties, which confer its traditional and contemporary uses as food and herbal medicine. A group researchers reviewed that various parts of 'Kaduk' such as leave, fruit and root, are widely used in Asian countries for ages to heal different types of diseases such as diarrhoea, dysentery, ulcers, cough, asthma, rheumatism, malaria and fungoid dermatitis [3]. Scientific findings demonstrated different pharmacological actions of various parts of $P$. Sarmentosum such as antituberculosis, antiangiogenic. The leaves are used as digestive tonic, carminative and expectorant. It has antituberculosis, antiplasmodial and antidiabetic effect [4]. Leaves of P. sarmentosum contain phenylpropanoids, phenylpropanoyl amides, dihydroflavones and essential oils. P. sarmentosum contains natural antioxidants like rutin, vitexin, naringenin, hesperitin, taxifolin/dihydroquercitin and quercetin which have high superoxide scavenging action and also other active compounds, for example, beta-sitosterol, stigmasterol, sarmentine, sarmentosine and pellitorine [5].
On the other hands, new and re-emerging diseases have become a major concern from medical practitioners. Some bacteria strains are evolving and have become resistant toward current antibiotics which can contribute to the development of new diseases and disorders causing global problem to human health [6]. Hence, scientists are working to find new effective antibacterial agents. The present research aimed to study the effect of methanolic extract of P. sarmentosum leaves on the growth of three Gram-positive bacteria namely, Staphylococcus saprophyticus (ATCC 15305), Staphylococcus aureus (ATCC 25923) and Bacillus subtilis (IMR B145/11C), and five Gram-negative bacteria which are Klebsiella pneumonia (ATCC 700603), Pseudomonas aeroginosa (ATCC 27853), Enterococcus aerogenes (ATCC 13048), Shigella flexneri (IMR S 430/07 B) and Salmonella typhimurium (IMR S 974/05 B).

\section{MATERIAL AND METHODS}

\subsection{Sample materials and preparation}

The leaf sample was cultivated at Kuliyyah of Science, International Islamic University Malaysia (IIUM) Kuantan campus. The mature leaves were collected and left to dry at room temperature. They were then blended into powder. $42 \mathrm{~g}$ of the leaf powder was weighed and transferred into thimble with $400 \mathrm{~mL}$ of methanol. The extraction process was carried out with Soxhlet apparatus. The resultant solutions were then concentrated to dryness by using a rotary evaporator.

\subsection{Test microorganisms and preparation}

\subsubsection{Media preparation}

Mueller Hinton (MH), Mueller Hinton Broth (MHB), Nutrient Agar (NA) and Nutrient Broth (NB) were prepared according to the manufacturer's 
standard protocol (Merck, Germany). Then, the mixture was sterilized by autoclaving it at $121^{\circ} \mathrm{C}$ for 2 hours. For the agar medium, the sterilized mixture was then poured into sterile agar plates and allowed to cool and solidify. The agar plates and broth were then kept at $4^{\circ} \mathrm{C}$ until further use.

\subsubsection{Test microorganism and inoculum preparation}

All bacteria stock cultures were obtained from the Microbiology Laboratory of Kulliyyah of Science, IIUM Kuantan. Fresh cultures were transferred into conical flask containing broth (Muller Hinton broth/Nutrient broth). The broth was incubated for 24 hours before the cultures were diluted to the desired McFarland Standard (0.5 McFarland turbidity standards which correspond to the microbial density of $1 \times 10^{8}$ $\mathrm{CFU} / \mathrm{mL}$ ). The list of organisms tested is shown in Table 1 as follow;

Table 1: List of test microorganism

\begin{tabular}{|l|l|l|}
\hline Bacteria & Strain & Gram group \\
\hline Bacillus subtilis & IMR B145/11C & Positive \\
\hline Enterococcus aerogenes & ATCC 13048 & Negative \\
\hline Klebsiella pneumonia & ATCC 700603 & Negative \\
\hline Pseudomonas aeruginosa & ATCC 27853 & Negative \\
\hline Salmonella typhimurium & IMR S 974/05 B & Negative \\
\hline Shigella flexneri & IMR S 430/07 B & Negative \\
\hline Staphylococcus aureus & ATCC 25923 & Positive \\
\hline Staphylococcus saprophyticus & ATCC 15305 & Positive \\
\hline
\end{tabular}

\subsubsection{Antibacterial Sensitivity Test}

\subsubsection{Disc Diffusion Method}

The effectiveness of crude extract was determined by standard protocol of disc diffusion method [7]. The test was conducted as the preliminary screening to evaluate the antibacterial activity of the extracts against the selected bacteria which were Staphylococcus saprophyticus, Staphylococcus aureus, B. Subtilis, K. pneumonia, P.aeroginosa, E.aerogenes, S. flexneri and S. Typhimurium. $100 \mu \mathrm{L}$ of the bacterial culture was spread evenly on the surface of the agar. $100 \mathrm{mg} / \mathrm{mL}$. In other study, they described the preparation of disc diffusion was done by preparing a concentration of $100 \mathrm{mg} / \mathrm{mL}$ of extract stock solution [8]. Sterile blank discs that were impregnated with $100 \%$ DMSO, chloramphenicol (1 $\mathrm{mg} / \mathrm{mL})$ and two different concentrations of extracts $(0.5 \mathrm{mg} / \mathrm{mL}$ and 1.0 $\mathrm{mg} / \mathrm{mL}$ ). The antibiotic and extracts impregnated disc were placed on the agar plates using sterile forceps. Chloramphenicol was used as the positive control and $100 \%$ DMSO as the negative control. The agar plates were incubated for 24 hours. Clear zone which represents the inhibition zone was observed and the diameter was measured in millimeter ( $\mathrm{mm}$ ).

\subsubsection{MIC Determination}

The test was conducted following the steps described with minor modification [9]. Minimum Inhibitory Concentration (MIC) is the lowest concentration that the extract can inhibit the bacterial growth [8]. The test was performed using 96 well microplates. Only the bacteria that showed clear zone of inhibition more than $10 \mathrm{~mm}$ of diameter after being introduced with extracts will be proceed to the MIC test which were the
Staphylococcus saprophyticus and Staphylococcus aureus. Serial twofold dilution technique was used to prepare the plant extract from $15 \mathrm{mg} / \mathrm{mL}$ to $0.12 \mathrm{mg} / \mathrm{mL}$ of concentration. The microplates were incubated for 24 hours.

\subsubsection{MBC Determination}

Minimum Bactericidal Concentration (MBC) corresponds to the lowest concentration in MIC test that showed no growth after sub-culturing the well content on fresh agar. The agar was incubated for 24 hours. After the incubation period, agar plates were examined for any bacterial growth.

\section{RESULTS AND DISCUSSION}

\subsection{Yield percentage}

The percentage of $P$. sarmentosum methanolic extract was calculated by using the following formula in Equation 3.1 as follow;

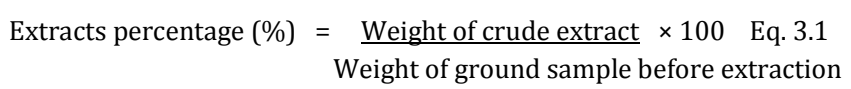

Percent yield of extracts obtained from $42 \mathrm{~g}$ of ground dried sample are as follow;

Table 2: Yield Percentage

\begin{tabular}{|l|l|l|}
\hline Sample & Extracts percentage (\%) & Mean percentage (\%) \\
\hline R1 & 40.5 & \multirow{2}{*}{39.5} \\
\cline { 1 - 2 } R2 & 39.5 & \\
\hline R3 & 38.5 & \\
\hline
\end{tabular}

Methanol, which is highly polar, was used as the solvent to extract all polar entities present in the samples. The mature leaves were grounded to fine powder. The rationale is the particle size of plant sample to be extracted is believed to be proportional to the extraction yield that can be obtained upon extraction. Therefore, using fine powder of leaves will increase the surface area for the solvent to interact, thus increasing the extraction yield [10].

\subsection{Antibacterial Sensitivity Tests}

\subsubsection{Disc Diffusion Method}

In this research, the antibacterial activity of methanolic extract of $P$. sarmentosum against three Gram-positive bacteria and five Gram-negative bacteria were assessed by measuring the zone of inhibition produced on the agar media. The result showed that two of the Gram-positive bacteria inhibited by the methanolic extract of $P$. sarmentosum, where both are Staphylococcus strains. However, the other six bacteria showed no or minimal effect from the extract. The positive control, chloramphenicol exhibited high susceptibility toward all tested bacteria, which is parallel to its antibiotic resistance profiles of 200 clinical isolates from each bacterial species [11]. Meanwhile, the negative control, DMSO provided no antibacterial activity in all tested bacteria. Table 3 summarizes the result of zone of inhibition for methanolic extract of P. sarmentosum.

Table 3: Observation of inhibition zone of methanolic extract of $P$. sarmentosum

\begin{tabular}{|l|l|l|l|l|l|}
\hline Microorganism & Observation & \multicolumn{3}{|l|}{ Diameter of inhibition zone (mm) } \\
\cline { 3 - 6 } & & $1.0 \mathrm{mg} / \mathrm{mL}$ & $0.5 \mathrm{mg} / \mathrm{mL}$ & $\begin{array}{l}\text { Chloramphenicol } \\
\text { (positive control) }\end{array}$ & DMSO (negative control) \\
\hline S. saprophyticus & & $17.3 \pm 0.3$ & $13.3 \pm 0.3$ & $28.0 \pm 0.0$ & - \\
& & & & & \\
\hline
\end{tabular}




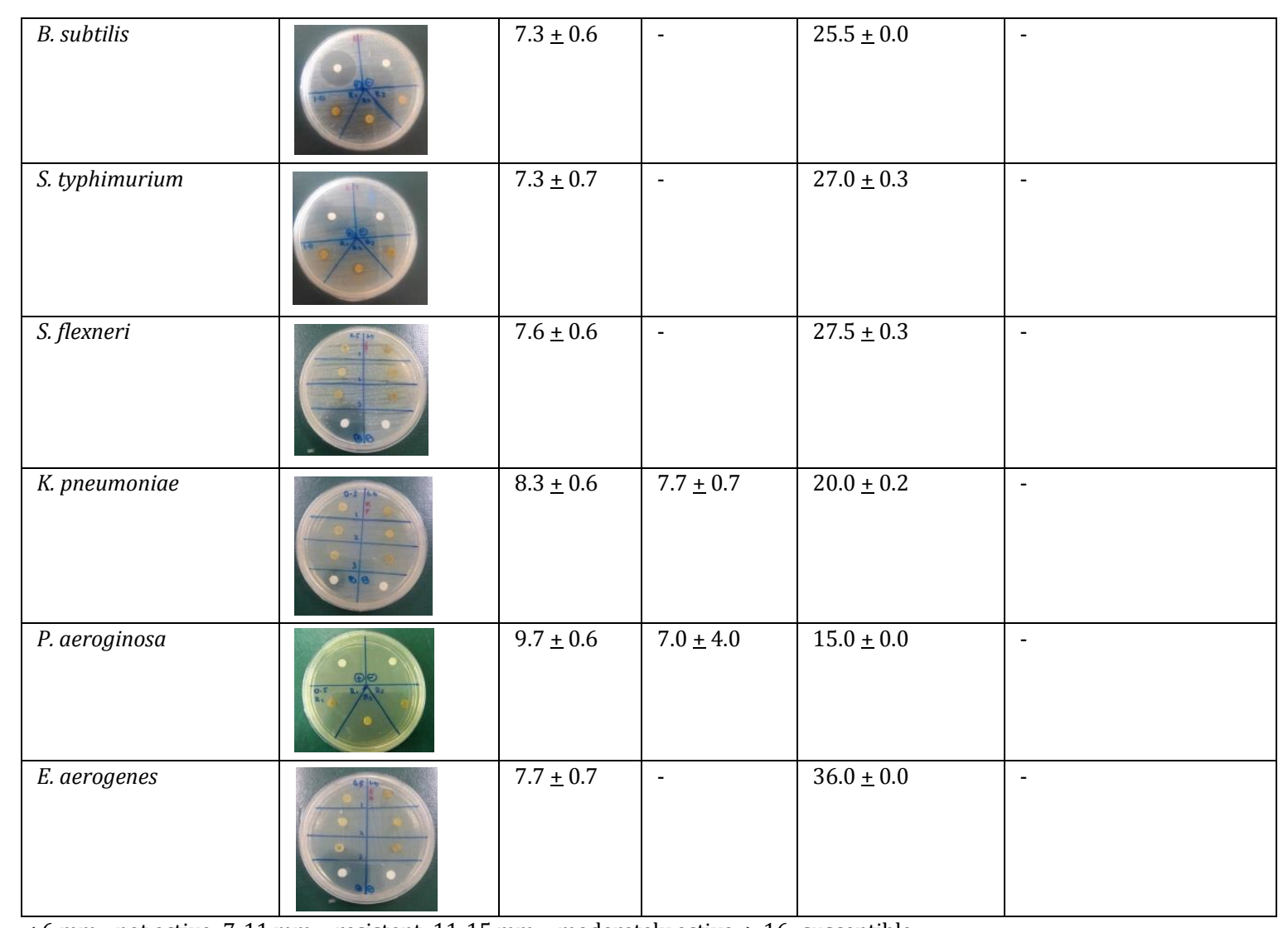

$<6 \mathrm{~mm}$ =not active; $7-11 \mathrm{~mm}=$ resistant; $11-15 \mathrm{~mm}$ = moderately active; $\geq 16=$ susceptible

Based on the study conducted, the leaves of $P$. sarmentosum did not inhibit the growth of $S$. aureus but inhibiting P. aeroginosa at concentration of 50 $\mathrm{mg} / \mathrm{mL}$ with $9 \mathrm{~mm}$ of inhibition zone, which was distinguishable this study [12]. Differences in extraction solvent provide different results. Methanol acts well as extraction solvent since it can extract polar compound from plant. Some researchers demonstrated antibacterial activity from active compounds isolated from the P. sarmentosum against Gram-positive bacteria but none on Gram-negative bacteria [13]. This result was correlated with this presented study where antibacterial activity could be observed in the tested S. saprophyticus and S. aureus of Gram-positive bacteria.

\subsubsection{Minimum Inhibitory Concentration (MIC)}

Table 4 shows the minimum inhibitory concentrations (MICs) of methanolic extract of $P$. sarmentosum. The result showed similar MIC value for both S. saprophyticus and S. aureus bacteria, which was at $7.5 \mathrm{mg} / \mathrm{mL}$.

Table 4: Minimum inhibitory concentrations (MICs) of P. sarmentosum extract

\begin{tabular}{|l|l|l|l|}
\hline \multicolumn{2}{|l|}{ Bacteria } & S.saprophyticus & S. aureus \\
\hline \multirow{5}{*}{$\begin{array}{l}\text { Concentration } \\
(\mathrm{mg} / \mathrm{mL})\end{array}$} & 15 & $\sqrt{ }$ & $\sqrt{ }$ \\
\cline { 2 - 4 } & 7.5 & $\sqrt{ }$ & $\sqrt{ }$ \\
\cline { 2 - 4 } & 3.75 & $\mathrm{x}$ & $\mathrm{x}$ \\
\cline { 2 - 4 } & 1.87 & $\mathrm{x}$ & $\mathrm{x}$ \\
\cline { 2 - 4 } & 0.94 & $\mathrm{x}$ & $\mathrm{x}$ \\
\cline { 2 - 4 } & 0.47 & $\mathrm{x}$ & $\mathrm{x}$ \\
\cline { 2 - 4 } & 0.23 & $\mathrm{x}$ & $\mathrm{x}$ \\
\cline { 2 - 4 } & 0.12 & $\sqrt{ }$ & $\mathrm{x}$ \\
\hline Controls & $\begin{array}{l}\text { Chloramphenicol } \\
\text { (positive) }\end{array}$ & $\sqrt{ }$ & $\mathrm{x}$ \\
\cline { 2 - 4 } & DMSO (negative) & $\mathrm{x}$ & \multicolumn{2}{|c|}{} \\
\hline
\end{tabular}

\subsubsection{Minimum Bactericidal Concentration}

Subsequent test Minimum Bactericidal Concentration (MBC) corresponds to the lowest concentration of extract that kills the microbes making them unable to grow even if provided with fresh agar media. This test was carried out to determine whether the clear well seen in MIC indicates that the active extracts are bactericidal agents (no bacterial growth observed on plates) or just bacteriostatic (only inhibit bacterial growth on plates). Result in Table 3.4 shows the minimum concentration of bacteria that can kill the bacteria.

Table 5: Minimum Bactericidal Concentration (MBC) of P. sarmentosum extract

\begin{tabular}{|l|l|l|}
\hline \multirow{2}{*}{ Tested bacteria } & \multicolumn{2}{|l|}{ Concentration $(\mathrm{mg} / \mathrm{mL})$} \\
\cline { 2 - 3 } & 15.0 & 7.5 \\
\hline S. saprophyticus & $\sqrt{ }$ & $\sqrt{ }$ \\
\hline S. aureus & $\sqrt{ }$ \\
\hline \\
$\begin{array}{l}\mathrm{X}=\text { no bacterial growth (growth within 3-5 single colonies) } \\
\sqrt{\mid}=\text { bacterial growth (growth exceeds the colony range for MBC) }\end{array}$
\end{tabular}

From the result evaluation, it indicates that the plant extract promotes bacteriostatic action toward the both $S$. saprophyticus and $S$. aureus bacteria.

\section{CONCLUSION}

The methanol extraction of $P$. sarmentosum using Soxhlet method was successful by yielding $39.5 \%$ of crude extract. The result indicates that the plant extract possess antibacterial activity against $S$. aureus and $S$. saprophyticus. However, both are found to be bacteriostatic which is only inhibiting the growth and not completely kill the bacteria. Meanwhile, for the other tested gram-negative and -positive bacteria, the result showed no or minimal antibacterial activity. Nevertheless, the finding suggests the $P$. sarmentosum is potent as antibacterial agent against staphylococcus bacteria and therefore suggested to be further studied for the purpose of pharmaceutical industry for disease treatment in the future.

\section{REFERENCES}

[1] Arifullah, M., Vikram, P., Chiruvella, K.K., Shaik, M.M., Ripain, I.H.B.A. 2014. A Review on Malaysian Plants Used for Screening of Antimicrobial Activity. Annual Research \& Review in Biology, 4 (13), 2088.

[2] Sukanya, S., Sudisha, J., Hariprasad, P., Niranjana, S., Prakash, H., Fathima, S. 2009. Antimicrobial activity of leaf extracts of Indian medicinal plants against clinical and phytopathogenic bacteria. African Journal of Biotechnology, 8 (23), 6677-6682. 
[3] Seyyedan, A., Yahya, F., Kamarolzaman, M.F.F., Suhaili, Z., Mohd, M.N., Desa, H.M.K., and Salleh, Z.A.Z. 2013. Review on the ethnomedicinal, phytochemical and pharmacological properties of Piper sarmentosum: scientific justification of its traditional use. Tang (Humanitas Medicine), 3 (3), 19-1.

[4] Hussain, K., Ismail, Z., Sadikun, A., Ibrahim, P. 2009. Antioxidant, antiTB activities, phenolic and amide contents of standardised extracts of Piper sarmentosum Roxb. Natural Product Research: Formerly Natural Product Letters, 23 (3), 238-249.

[5] Ugusman, A., Zakaria, Z., Hui, C.K., Nordin, N.A. 2011. Piper sarmentosum inhibits ICAM-1 and Nox4 gene expression in oxidative stress induced human umbilical vein endothelial cells. BMC Complement Alternative Medicine, 11, 31

[6] Sibanda, T., Okoh, A.I. 2007. The challenges of overcoming antibiotic resistance: Plant extracts as potential sources of antimicrobial and resistance modifying agents. African Journal of Biotechnology, 6 (25), 2886-2896.

[7] Kirby, W.M.M., Yoshihara, G.M., Sundsted, K.S., Warren, J.H. 1957. Clinical usefulness of a single disc method for antibiotic sensitivity testing. Antibiotics Annual, 1956-1957, 892.
[8] Fernandez, L., Daruliza, K., Sudhakaran, S., Jegathambigai, R. 2012 Antimicrobial activity of the crude extract of Piper sarmentosum against methicilin-resistant. European Review for Medical\&Pharmacological Sciences, 16, 105

[9] Othman, A.S., Rasyidah, M.R. 2010. Antibacterial activity of aleurites moluccana against some clinical isolates. Research Journal of Biotechnology, 5 (3), 25-30.

[10] Tiwari, P., Kumar, B., Kaur, M., Kaur, G., Kaur, H. 2011. Phytochemical screening and Extraction: A Review. Internationale Pharmaceutica Sciencia, (1), 98-106.

[11] Surasak, L., Sanan, S., Supayang, V. 2009. Medicinal plants with significant activity against important pathogenic bacteria. Pharmaceutical Biology, 47 (8), 683-689.

[12] Puzi, S.H., Samah, O.A., Sule, A. 2011. Selective antimicrobial activity of Piper sarmentosum (Kaduk) against Pseudomonda aeruginosa. Current Topics in Nutraceuticals Research, 9 (1/2), 31.

[13] Atiax, E., Ahmad, F., Sirat, H.M., Arbain, D. 2011. Antibacterial activity and cytotoxicity screening of sumatran kaduk (Piper sarmentosum Roxb.). Iranian Journal of Pharmacology and Therapeutics, 10 (1), 1-5. 